\title{
South American fish species suitable for aquaponics: a review
}

\author{
Sara M. Pinho ${ }^{1,2}$ (D) - Luiz H. David ${ }^{1}$ (D) $\cdot$ Fabiana Garcia $^{1,3}\left(\mathrm{D} \cdot\right.$ Karel J. Keesman $^{2}$ (D) \\ Maria Célia Portella ${ }^{1}$ (D) Simon Goddek ${ }^{2}$ (D)
}

Received: 4 September 2020 / Accepted: 16 February 2021 / Published online: 11 March 2021

(C) The Author(s) 2021

\begin{abstract}
Tilapia and catfish are the most popular fish species in aquaponics. However, they are not well-accepted in all markets, and finding alternative species is important in order to increase the variety of food products and meet market demands. South America has several potential fish species for aquaponics systems. Encouraging the implementation of integrated aquaculture systems by providing information about the production of South American species can help to increase the supply of high-quality food and aquaculture diversification. Thus, data for five South American fish species with potential for aquaponics were compared with existing data for the main traditional warm water species in this system, tilapia and catfish. Moreover, the degree of suitability of the novel species for these systems in terms of zootechnical performance, tolerance to water quality and nutritional composition of fish flesh were discussed. The South American species considered were jundia or silver catfish (Rhamdia quelen), yellowtail lambari (Astyanax lacustris), pacu (Piaractus mesopotamicus), tambaqui (Colossoma macropomum) and snook (Centropomus spp.). Their description and the tabular comparison with the most traditional aquaponic-cultured species show they are suited for this production system. How suitable they are will depend on the system design, as well as the regional characteristics of the market where they will be produced.
\end{abstract}

Keywords Aquaponics · Integrated food production · Food security · Aquaculture diversification

Sara M. Pinho and Luiz H. David contributed equally to this work.

Handling Editor: Hendrik Monsees

This article is part of the Topical Collection on Aquaponics and Biofloc

Karel J. Keesman

karel.keesman@wur.nl

Maria Célia Portella

maria.c.portella@unesp.br

Extended author information available on the last page of the article 


\section{Introduction}

A food production system is considered sustainable when it efficiently uses natural resources to produce high-quality food for human consumption (Wunderlich and Martinez 2018; Wilfart et al. 2013). Aquaponics has been recognized as a sustainable food production system, as it reuses a large proportion of its internal waste streams. It is defined as an integrated multitrophic aquatic food production method, which contains at least one direct connection between an aquaculture and a plant production unit (Lennard and Goddek 2019). Aquaponics is already widely applied in many developed countries (Villarroel et al. 2016; Love et al. 2014).

Food supply in South American countries is mainly based on monocultures; aquaagriculture-integrated food production systems are not yet widespread (Rodrigues et al. 2019; Liu et al. 2018). Monocultures are one of the causes of the overexploitation of both the soil and natural resources (Hampf et al. 2020; Joyce et al. 2019; de Castro et al. 2014) and, in the long run, are inefficient in supplying the local population with healthy food. In addition, the social problems faced by many South American countries contribute to their current levels of malnutrition (PAHO 2020) and increase the need for efficient food production systems. In 2017, the annual freshwater fish production per capita in South America was below the worldwide average, $3.2 \mathrm{~kg}$ vs. $8.2 \mathrm{~kg}$ respectively, and the average of vegetable and fruit supply was also low: $51.6 \mathrm{~kg}$ per capita in South America vs. $135.7 \mathrm{~kg}$ per capita worldwide (FAO 2020).

Providing information on the production of South American species in aquaponics systems can encourage the implementation of these systems, and therefore help to minimize the continent's problems related to high-quality food supply and the pressure on natural resources. Compared to cage and pond-based aquaculture systems, both recirculating aquaculture systems (RAS) and aquaponics need lower volumes of water and smaller areas of land to produce fish (Oladimeji et al. 2020; Lennard and Goddek 2019; Martins et al. 2010). In aquaponics, some of the negative effects of fish production, such as nutrient-rich effluent discharge, can be reduced through nutrient reuse by plants and energy/nutrient recovery after waste treatment by implementing additional technologies (Goddek et al. 2019a). Moreover, chemical and antibiotic-free fish and pesticide-free plants are produced, which makes this system useful in promoting food security (Kyaw and $\mathrm{Ng}$ 2017).

Regarding the most common aquaponics design (i.e. coupled or one-loop aquaponics system), the process water is fully recirculated between the RAS and the hydroponics unit (Yep and Zheng 2019; König et al. 2018). An alternative configuration is known as the decoupled aquaponics system (DAPS), where the respective subsystem components can be seen as stand-alone systems. This allows for optimal conditions to produce both fish and plants (Monsees et al. 2017). In addition, multi-loop aquaponics systems have also been introduced (Lennard and Goddek 2019) that can comprise additional loops containing digestion units (Delaide et al. 2019) and/or desalination units (Goddek and Keesman 2018). Such additional loops are added to the system to increase the nutrient and water reuse efficiency of the overall system. For example, nutrient mineralization and mobilization units in the form of bioreactors can be used to reduce the need for additional fertilizers in the hydroponics unit. Desalination technology can be used to extract nutrients from the RAS water in a highly concentrated form and provide it to the hydroponics unit (Goddek and Keesman 2018). Regardless of the chosen design, it is important to make a careful selection of the fish and plant species that will be grown, in order to both optimize nutrient utilisation and achieve maximum profitability. 
With respect to the fish species, tilapia (Oreochromis niloticus) and several catfish (order Siluriformes) are the most traditional warm water species for aquaponics (Yep and Zheng 2019; Mchunu et al. 2018; Love et al. 2015). However, these species are not well-accepted in all markets. This is because tilapia is usually masculinized with steroid hormone (Joshi et al. 2019; Golan and Levavi-Sivan 2014) and there is a high dependence on antibiotics to achieve high yields (Roriz et al. 2017). Also, catfish is known as a fish potentially containing heavy metals as it is conventionally reared using water from contaminated rivers such as the Mekong Delta (Vietnam) and Lake Rukwa (Tanzania) (Mapenzi et al. 2020; Madsen et al. 2015). In general, consumers of these species are concerned that undesirable substances have entered the food chain, especially due to the deposit of residues in the fish flesh (Zhong et al. 2016; Megbowon and Mojekwu 2014). Furthermore, tilapia and the most popular catfish (Ictalurus punctatus, Pangasius pangasius, Clarias gariepinus) are exotic in South American countries and, if accidentally released into the environment, could become predators of native species (Padial et al. 2017; Bittencourt et al. 2014).

As stated above, the search for alternative species for aquaponics production is important to meet market demands. This will increase the variety of available food products, allowing farmers to produce species that match local characteristics (Pinho et al. 2017; Goddek et al. 2015), and encourage aquaculture diversification (FAO 2016). The nutritional quality and flesh safety of the fish produced are also important factors when selecting suitable species. Fish is recognized as one of the best animal proteins, being highly digestible and an important source of essential fatty acids (Pal et al. 2018; De Smet 2012) and other nutrients for human health (Tilami and Sampels 2018).

South America is home to the largest biodiversity of fish in the world (Reis et al. 2016) and several species have been identified as potential candidates for aquaculture production. In some South American countries, native fish are already widely produced in pond or cage systems (Valladão et al. 2018). However, the feasibility of producing these species in aquaponics is still not well known. In this review, we compare five South American fish species with potential for aquaponics with the main traditional warm water species in this system, i.e. tilapia and catfish. We also discuss the degree of suitability of the novel species for different kinds of aquaponics systems in terms of zootechnical performance, tolerance to water quality and nutritional composition of fish flesh.

\section{What makes a fish species suitable for aquaponics?}

From a fish production perspective, aquaponics is bound to the same chemical, physical and biological conditions that occur in RAS (Espinal and Matulić 2019). This means that, just like in RAS, fish species must show some overall characteristics in order to be produced intensively in aquaponics systems, such as a tolerance to both high densities and high levels of total suspended solids and dissolved nutrients (Yep and Zheng 2019). Maintaining fish welfare is also necessary in these systems since it boosts their health and allows the fish to reach their maximum growth potential (Yildiz et al. 2017). In small-scale or hobby aquaponics systems, these are usually the only characteristics considered. However, for commercial productions, some additional specific points must be taken into account and they differ for coupled and decoupled systems.

In coupled systems, the aquaculture, hydroponics and biological filter units are interconnected; therefore, finding a trade-off between the proper water conditions for each subsystem 
is required (Palm et al. 2019). The choice of fish species in coupled aquaponics should depend on the crop grown. This is because plants are often the main source of income (Bosma et al. 2017) and, to keep the facility profitable, meeting plant requirements without harming fish growth or filter operation is desired. In these systems, the fish should be rustic and tolerate a wide range of physical-chemical water parameters. The fish should also tolerate high concentrations of macro and micronutrients which are often added to the water as a supplement for plant growth (Yildiz et al. 2017). In coupled aquaponics, the optimal conditions in each subsystem cannot be reached without either harming fish growth and survival or causing the plants to grow very slowly and show nutrient deficits. Achieving good economic system efficiency is a huge challenge when dealing with the trade-offs in terms of temperature, $\mathrm{pH}$ and nutrient concentration (measured in electrical conductivity) (Goddek et al. 2019b).

The range of species that can be produced in DAPS or in decoupled multi-loop systems is, in general, larger than in coupled systems (Fig. 1). This is due to the possibility of meeting the specific required economic conditions of each loop in decoupled systems, mainly in relation to abiotic factors, such as water and environmental conditions, and to nutrient balances (Danner et al. 2019; Goddek and Körner 2019). Once the requirements of the aquaculture loop are met, fish become an important aquaponics product and the choice of species becomes directly dependent on their market acceptance, production costs and growth rate. In DAPS, fish species with favourable characteristics for intensive RAS production can be selected, as outlined above.

\section{South American fish species}

The South American continent is recognized for its great potential for aquaculture production. This is due to its water availability, favourable climate conditions, high variety of species (FAO 2018a; Valladão et al. 2018) and access to technical-scientific knowledge, equipment, supplies and manpower. Valladão et al. (2018) reviewed South American fish for continental aquaculture and described the main fish species, producing countries and systems or used techniques. The potential of such species for aquaponics systems was not evaluated. Based on their characteristics, we consider that the main alternative species that might be interesting for using in freshwater aquaponics systems are the silver catfish jundia (Rhamdia quelen), yellowtail lambari (Astyanax lacustris spp.), pacu (Piaractus mesopotamicus), tambaqui (Colossoma macropomum) and snooks (Centropomus spp.). The reason to review these species, among several others reared in South America, was due to their market value, nutritional quality for consumption and/or the large volume produced in conventional systems.

\section{Coupled systems}

Fish is usually a secondary aquaponics product
Decoupled systems Fish is an important aquaponics product

$\begin{array}{lc}\text { Tolerate high } & \text { Capable to be } \\ \text { concentrations of } & \text { produced in } \\ \text { nutrients in water } & \text { intensive RAS }\end{array}$

High growth rate Market acceptance Low production costs

Fig. 1 The overall characteristics that fish species must have to be productive in coupled and decoupled aquaponics systems 
A brief description of each one and a tabular overview are presented below. Photos of each species are presented in Fig. 2. The water quality, zootechnical and nutritional parameters are shown in Table 1. Data related to RAS and aquaponics systems were prioritized. In case no data was found, values from other production systems were reported and identified. With respect to the water quality, value ranges or maximum tolerable values of the main parameters suitable for each species were presented. The zootechnical and nutritional parameters were described according to the maximum values found for intensive cultures. For the stocking density, the values found for intensive cage systems were considered. The market characteristics for each species, such as harvest weight, mean values of nutritional composition for consumers and sale price, are summarized in Table 2.

In addition to the aforementioned species, a wide variety of fish should be considered in the future, especially hybrids of the "round fishes", for instance, tambacu (C. macropomum $\mathrm{x}$ $P$. mesopotamicus), paqui ( $P$. mesopotamicus x C. macropomum), tambatinga (C. macropomum x Piaractus brachypomus), which were developed to be reared under different climatic conditions and to present better zootechnical results than the pure species (Hashimoto et al. 2012). However, insufficient productive results about them are available. In the case of the hybrids, their sustainability is uncertain due to lack of knowledge of their impact on the environment and effects on future generations of fish (Hashimoto et al. 2011).

\section{Jundia or silver catfish (Rhamdia quelen)}

The jundia (Fig. 2a) occurs naturally from southeast Mexico to Argentina. It is a suitable species for aquaculture in regions with a temperate or subtropical climate due to its optimal growth in summer and also its ability to withstand the temperatures of the South American winter (Abreu et al. 2016). In addition, jundia presents a high prolific rate, resistance to handling and high weight gain (Barcellos et al. 2009; Meyer and Fracalossi 2004). Reproductive management of this species is already dominated by the productive sector, with juvenile supply occurring from August to March (Barcellos et al. 2001). Its production has increased markedly because of the absence of intramuscular bones and high acceptance by consumers (Gomes et al. 2000). Under optimal conditions, it is possible to produce market size fish (800g) within 8 months (Barcellos et al. 2009). In the last decade, the total production of jundia has been decreasing (FIGIS-FAO 2020), mainly due to the increased production of exotic species, such as carp and tilapia (Baldisserotto 2008). From 2000 to 2010, the average annual volume produced was approximately 1000 tonnes, while in the following years, this average dramatically fell to 15 tonnes per year (FIGIS-FAO 2020).

No commercial production data of jundia in RAS or aquaponics is available. In experimental systems, the rearing of this species has been carried out for different purposes. Research with jundia in RAS includes evaluations of its reproduction (Goes et al. 2017; Tessaro et al. 2012; Coldebella et al. 2011), larviculture (Sulis-Costa et al. 2013; Uliana et al. 2001), productive management (Battisti et al. 2020; Owatari et al. 2018), nutrition (Yamashita et al. 2020; Ha et al. 2019; Battisti et al. 2017; Gominho-Rosa et al. 2015) and health (Cunha et al. 2018; Tancredo et al. 2015). These articles did not envision evaluating the growth performance of jundia in RAS compared to other production systems. However, their results showed that the species performs well in RAS environmental conditions.

To date, only two reports have been published about jundia reared in aquaponics. Rocha et al. (2017) evaluated the use of biofloc technology on the production of lettuce and jundia in a coupled aquaponics system. They demonstrated that it is possible to produce this fish in 
aquaponics and that the use of bioflocs did not influence the lettuce growth results. Araújo (2015) studied different feeding rates (7, 12 and $18 \mathrm{~g}$ per day) in the integration of jundia and cherry tomato (Solanum lycopersicum, var. Cerasiforme) produced in a coupled system. The author reported a difference between the optimum feeding rate for plants (12 g) and for fish (18 g) after 88 days of experiment. These results indicate the importance of continued investigation into jundia in aquaponics, particularly in decoupled systems, where the conditions can be adjusted to allow optimum performance for fish and plants.

\section{Yellowtail lambari (Astyanax lacustris)}

Yellowtail lambari (Fig. 2b), also known as yellowtail tetra or freshwater sardine, is a small (approximately $10 \mathrm{~cm}$ ) and rustic fish from the Characidae family. The Astyanax genus is one of the most specious of the order Characiformes, encompassing more than 100 species distributed over the Neotropical region (Kavalco 2008). The species yellowtail lambari, present in the Upper Paraná Basin, was classified for many years as Astyanax bimaculatus (Linnaeus 1758). However, the systematic phylogeny of the Astyanax genus was reviewed, and it was found that Astyanax bimaculatus did not correspond to only one species, moving the yellowtail lambari to the denomination of Astyanax altiparanae (Garutti and Britski 2000; Garutti 1995). Later, the species Astyanax altiparanae was considered a synonym of Astyanax lacustris (Lütken 1875), which became the valid name of the species (Lucena and Soares 2016). All of these nomenclatures were considered in the literature review.

Yellowtail lambari is a species with a fast life cycle usually produced in semi-intensive rearing ponds (Silva et al. 2011), reaching the commercial size (10-15 g, Sussel 2015) within 3 months (Valladão et al. 2018; Garutti 2003). However, lambari is also suitable for production in intensive systems (Porto-Foresti et al. 2010; Garutti 2003). Yellowtail lambari females develop earlier than males; therefore, their production would be more interesting. However, sex separation or manipulation is not commercially applied, and mixed-sex populations have been reared by producers (Fonseca et al. 2017). Regarding its market factors, yellowtail lambari is usually sold per unit and appreciated as snacks or used as live bait, mainly in the Brazilian Southeast region (Valladão et al. 2018). The high demand for lambari in the Brazilian Southeast region probably boosted the local rearing of this species, representing in 2016 more than half of the 595.6 tonnes produced in this country (IBGE 2018). The production chain of lambari was described by Silva et al. (2011), showing that most of the lambari commercialized as snacks still originate from fisheries. The species is widely consumed, highly valued and is considered an alternative fish species for small family farmers, since on small pieces of land they can obtain a high income (Silva et al. 2011; Fonseca et al. 2017).

Yellowtail lambari is a promising species for aquaponics. Sussel (2015) reported that its culture has been carried out in ponds, cages, RAS and aquaponics systems. The author points out that natural food must be available to lambari during the first month, and after this period, it should be transferred to closed and intensive production systems. However, to date, only a few

Fig. 2 The five South American fish species with potential for use in aquaponics systems. a Jundia (Rhamdia quelen) juvenile, $23 \mathrm{~cm}$ total length (TL) (photo credit: Eduardo Antônio Sanches). b Adult yellowtail lambari (Astyanax lacustreis), $8 \mathrm{~cm}$ TL (photo credit: Emerson Durigon). c Pacu (Piaractus mesopotamicus) juvenile, $28 \mathrm{~cm}$ TL (photo credit: Eduardo Abimorad). d Adult tambaqui (Colossoma macropomum), $70 \mathrm{~cm}$ TL (photo credit: Jenner Menezes). e Common snook (Centropomus undecimalis) juvenile, $14 \mathrm{~cm}$ TL (photo credit: Flávio F. Ribeiro) 
a

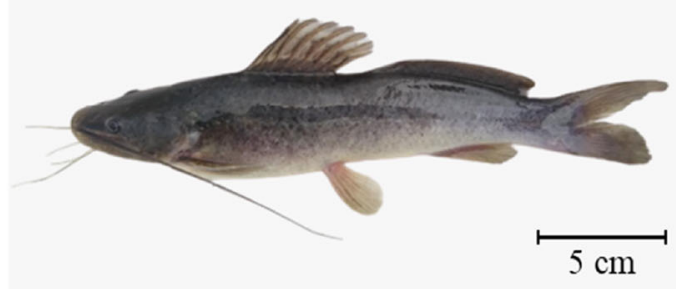

b

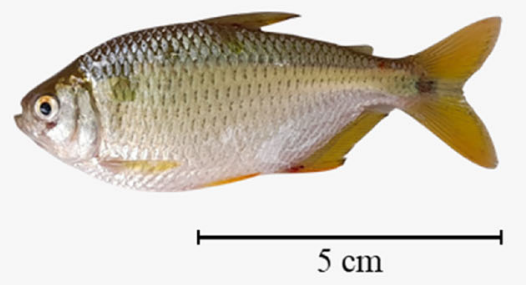

C

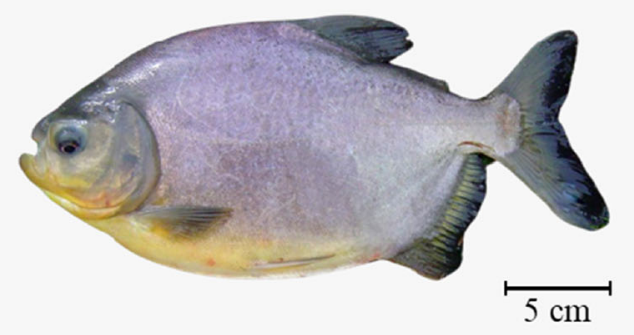

d

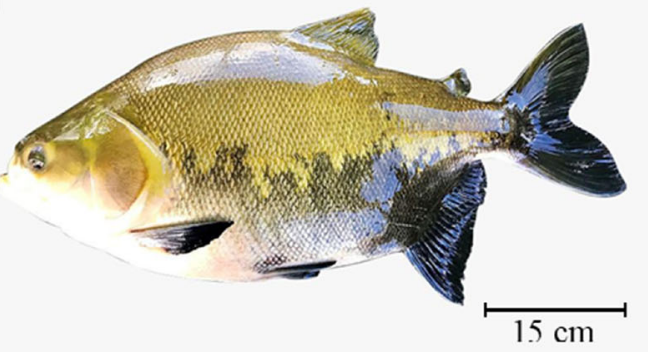

e

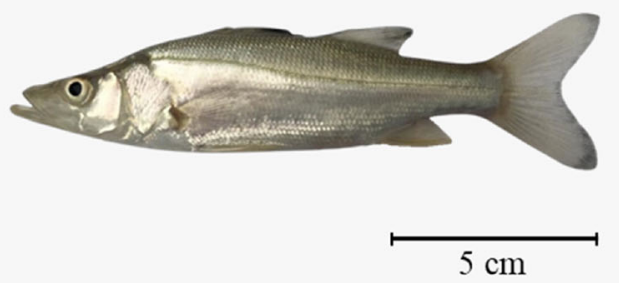




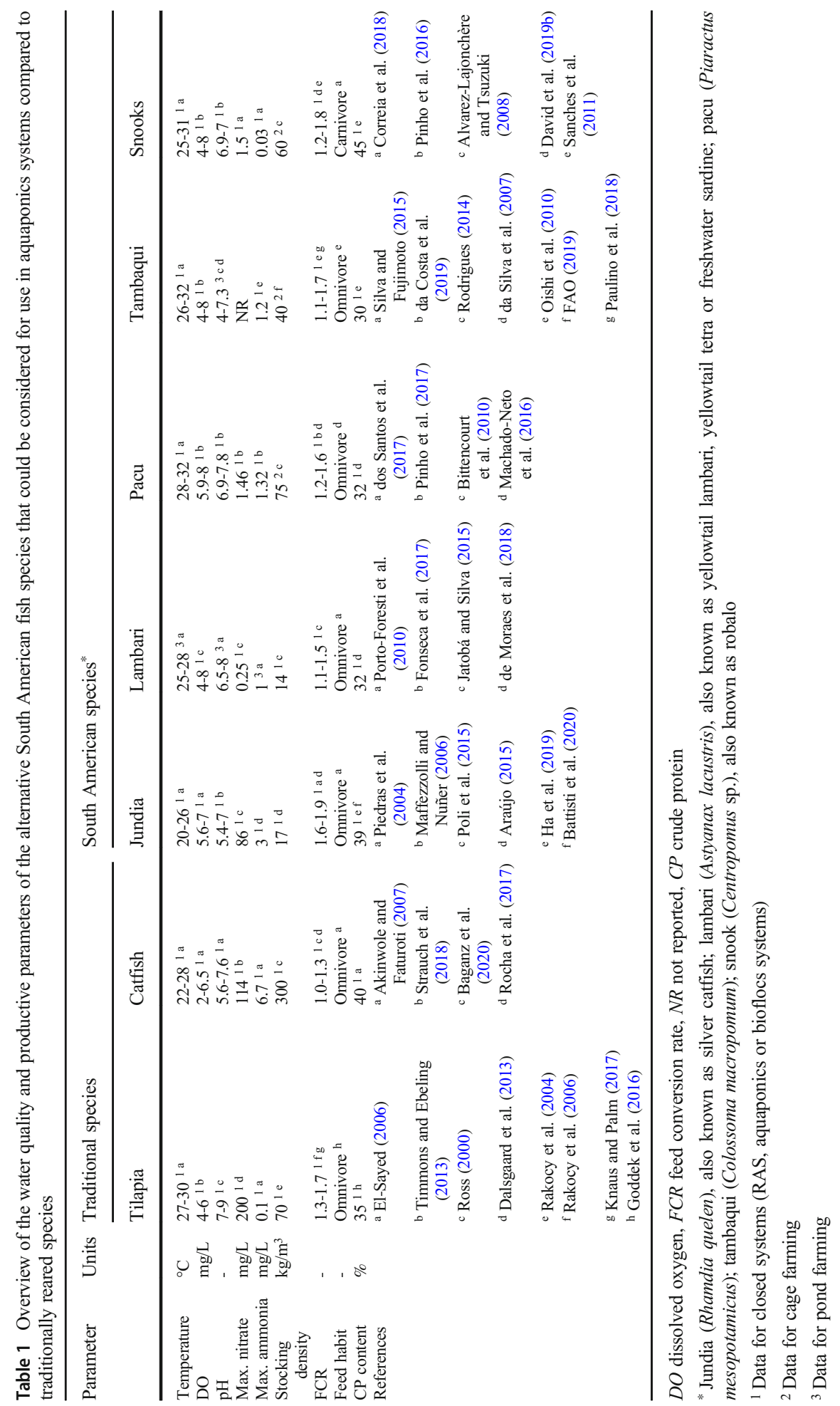




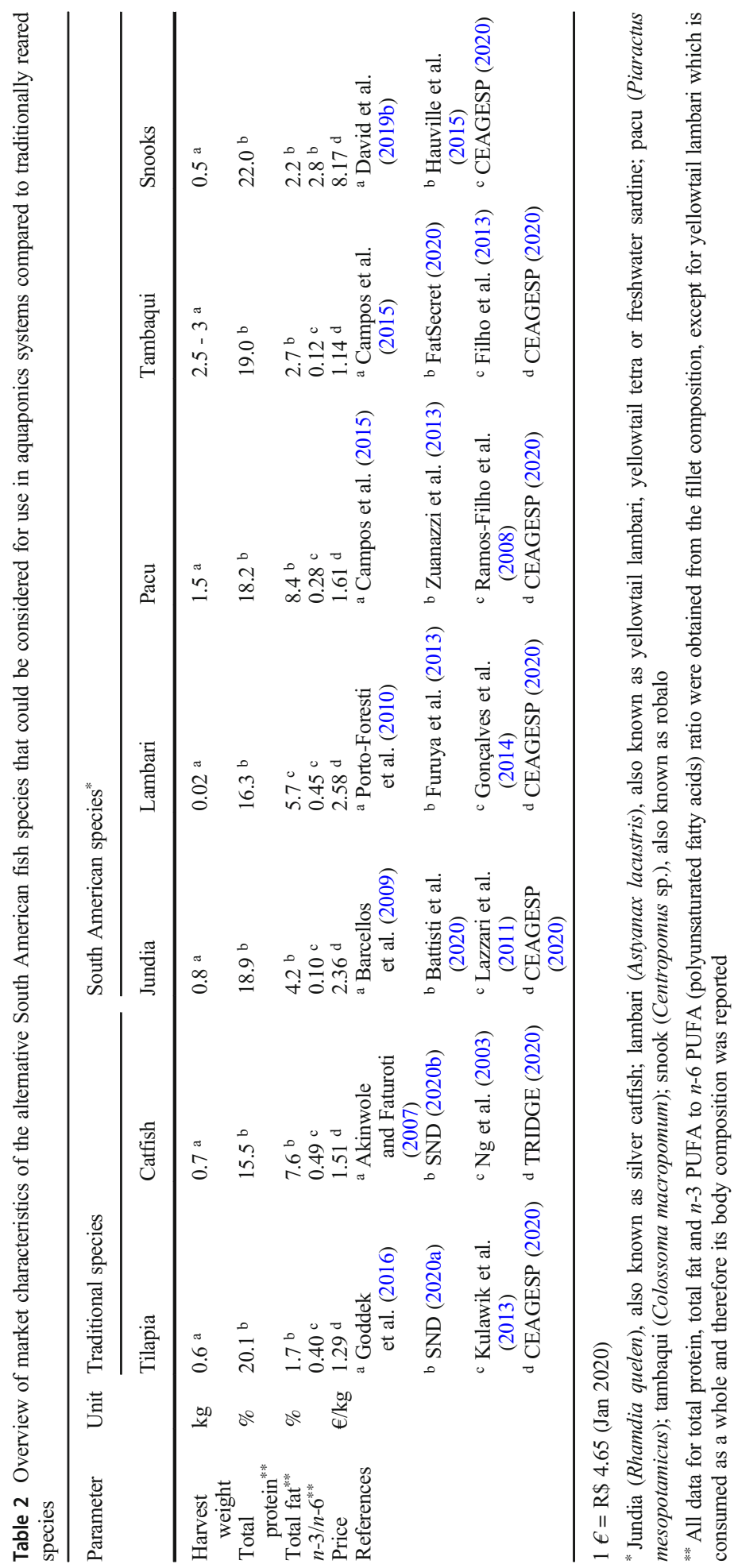


studies with yellowtail lambari in RAS have been performed (de Moraes et al. 2018; Lira et al. 2018; Jatobá and Silva 2015) and no scientific information about its production in aquaponics has been published. In Brazil, the production of yellowtail lambari in aquaponics systems was initially developed by The Sao Paulo Agency of Agribusiness Technology and was applied in small coupled systems. However, the technology is in its early stages of implementation and the transferring of the production model to commercial scale is still to be achieved (AEAARP 2015).

\section{Pacu (Piaractus mesopotamicus)}

Pacu (Fig. 2c) is one of the most commercially valuable fish in Brazilian fish farming and there is also a huge interest in its production in other South American countries along the Paraná River Basin, such as Paraguay, Uruguay and Argentina (David et al. 2019a; Valladão et al. 2018; Portella et al. 2014; Portella and Dabrowski 2008; Hashimoto et al. 2011). Pacu is valued as a table fish due to its high quality and tasty white meat and as game fish in view of its behaviour in continental sport fishing (David et al. 2019a; Furuya et al. 2008). Its production has been promoted by its being a rustic, omnivorous species with easy acceptance of formulated feed and intensive systems (David et al. 2019a; Nunes et al. 2013; Portella et al. 2012). This allows production of fish of approximately $1.3 \mathrm{~kg}$ in the first 12 months (Urbinati and Gonçalves 2005). In aquaculture systems, the reproduction of $P$. mesopotamicus is only possible by hormonal induction, and the supply of juveniles in the South American continent occurs between October and March (Portella et al. 2014; Urbinati and Gonçalves 2005).

Pacu has been mainly reared in Argentina and Brazil, and its production occurs widely via semi-intensive techniques in ponds (Valladão et al. 2018). In 2016, approximately 1950 tonnes of pacu was produced in Argentina, representing 52\% of the total aquaculture production in this country (FAO 2018b), and 11,570 tonnes in Brazil (IBGE 2018). This species is easily adaptable to intensive production in cages (Hilbig et al. 2012; Bittencourt et al. 2010); however, in ponds, low production density varying from 0.5 to $2 \mathrm{~kg} \mathrm{~m}^{-2}$ is usually reported (Valladão et al. 2018). The technical viability of pacu culture in closed systems was described only for larviculture (Jomori et al. 2003) and juvenile production (David et al. 2019a; Machado-Neto et al. 2016) phases, while no information on commercial or experimental production in RAS for the growth-out phase is available. In aquaponics systems, pacu is commonly reported as a species that is already being produced (Yep and Zheng 2019; Martins 2017; Rakocy 2012). Love et al. (2015) interviewed more than 1000 aquaponists of different scales around the world and found that pacu was among the farmed fish produced. Pinho et al. (2017) evaluated pacu and tilapia growth performance and the use of effluent from each species to produce two varieties of garnish (scallion and parsley) in coupled aquaponics systems. They showed that plant growth was not affected by fish species cultured and that pacu is a viable alternative species for aquaponics production. Fed with a diet containing $32 \%$ of CP and reared in an average temperature of $27^{\circ} \mathrm{C}$, it grew at a specific rate of $2.35 \%$ day $^{-1}$ and showed a feed conversion rate of 1.6 (Pinho et al. 2017).

\section{Tambaqui (Colossoma macropomum)}

Tambaqui (Fig. 2d) is a well-known Amazonian fish, mainly reared and consumed in countries such as Brazil, Colombia, Peru and Venezuela, although some production of tambaqui is also found in several Asian countries (FAO 2019). In 2016, approximately 142,100 tonnes of 
tambaqui was produced in these South American countries (FAO 2018a). Currently, it is the number one native species reared in several countries of the South American continent (FAO 2018a). The popularity of tambaqui in the aquaculture sector is due to its fast growth rate, the acceptance of commercial feed, relative resistance to diseases and tolerance of low water quality (Lima et al. 2019; Oishi et al. 2010). This species is highly prolific; its reproduction is achieved by hormonal induction during the breeding season (Rodrigues 2014), resulting in high availability of tambaqui juveniles (Gomes et al. 2010). Achieving the harvest weight of $3.5 \mathrm{~kg}$ is possible within 2 years under general fish farm conditions, although the market size of aquacultured tambaqui in Brazil is around $500 \mathrm{~g}$ (Pantoja-Lima 2020) to 2.5-3 kg (Almeida et al. 2016; Campos et al. 2015). Tambaqui flesh is a traditional protein source for the local Amazon population, where its meat is in great demand (da Costa et al. 2019), and also appreciated in other regions in the continent. However, like other Characid species, tambaqui has intramuscular bones, which makes its filleting for sale in foreign markets difficult (Perazza et al. 2017). An alternative that has been explored to increase its acceptability is the processing in different cuts, mainly the sale of its ribs (Cartonilho and de Jesus 2011). More recently, a programme to genetically select tambaqui that do not present these intramuscular bones started in Brazil (Perazza et al. 2017).

The aquaculture sector has invested in technologies to shift tambaqui production from conventional semi-intensive systems to more intensive production systems using RAS (Lima et al. 2019; Silva and Fujimoto 2015). However, only experimental results on the production of this species in RAS have been published so far. As reported for jundia, the investigations carried out with tambaqui used RAS as an experimental system to evaluate other productive management systems or parameters, and they were not specifically designed to evaluate the growth performance of tambaqui in such systems. These studies mainly focused on nutrition (Paulino et al. 2018; Júnior et al. 2017; Nwanna et al. 2008), reproduction (Gallego et al. 2017; Maria et al. 2015), management (Dantas et al. 2020; da Costa et al. 2019), behaviour (Reis et al. 2019; Barbosa et al. 2009), genetics (Ariede et al. 2020; da Silva et al. 2019) and health (Barbas et al. 2020; Paz et al. 2019). Lima et al. (2019) evaluated different stocking densities of tambaqui juveniles in RAS. Although these authors did not compare RAS with other production systems, they contrasted their findings with results reported for pond and cage systems and showed RAS as a potential system for intensive tambaqui production.

No published articles reporting the use of C. macropomum in aquaponics were found, except for a few abstracts presented at scientific conferences (Araújo et al. 2017; Cruz et al. 2015; Ibrahim et al. 2015), all of them with anecdotal and inconclusive results. However, researchers from the Brazilian Agricultural Research Corporation (EMBRAPA) described in a technical report the development of compact coupled systems for the aquaponics production of tambaqui and vegetables at the family production level, and in modular systems for large-scale production (Carneiro et al. 2015). They reported satisfactory growth of vegetables and the possibility of reaching the commercial weight of tambaqui in a similar period to that observed in conventional systems.

\section{Snook (Centropomus sp.)}

The species from genus Centropomus present favourable characteristics for aquaculture in recirculating systems, such as fast growth, acceptance of formulated diets, potential for very high biomass yields per unit volume in the nursery and grow-out systems and high market value (Pinho et al. 2016; Alvarez-Lajonchère and Tsuzuki 2008). The twelve snook species are 
known as "robalo" in Latin America. The common snook (Centropomus undecimalis) (Fig. $2 \mathrm{e}$ ) is the fastest-growing snook species and, together with the fat snook (Centropomus parallelus), is the most cultivated species under experimental conditions (Alvarez-Lajonchère and Tsuzuki 2008). They are diadromous, euryhaline, stenothermic and estuarine-dependent fish found in rivers, estuaries and coastal lagoons and along rocky shores (Mello et al. 2015; Pope et al. 2006). Studies have demonstrated that snooks have high osmoregulatory capacity, which allows them to maintain their internal osmotic pressure practically independent of external salinity concentrations (0-40 ppt) and to be produced in fresh water (Michelotti et al. 2018; Liebl et al. 2016; Gracia-López et al. 2006). Moreover, they are highly prized for the quality of their meat and valued for sport fishing (Passini et al. 2019). Processing the fillet is easy, with high yield ( 42\%), and its market value is usually high (David et al. 2019b; Cerqueira 2010).

There are still some constraints to the commercial production of snooks, such as their carnivorous habit (requiring diets with high protein content) and difficulties during the hatchery phase. However, the experimental results of reproduction and growth out are promising (Passini et al. 2019; Michelotti et al. 2018; Alvarez-Lajonchère and Tsuzuki, 2008). Researchers from Mexico reported the production of $800 \mathrm{~g}$ snook in 1 year (Sanchez-Zamora et al., 2003). Most of the experiments conducted with snook have been carried out in RAS, and aimed at understanding their reproductive biology (Passini et al. 2018; 2019), nutrition (Michelotti et al. 2020; David et al. 2019b), adequate stocking densities (Sanches et al. 2011) and optimal water parameters, especially temperature and salinity (Michelotti et al. 2018; Mello et al. 2015). However, in the field of aquaponics, snooks are still unknown and no reports of their production in these systems were found.

\section{Discussion}

The South American fish species with the potential to be produced in aquaponics have been described. Moreover, the main productive data of these species along with required water quality have been tabulated to enable a comparison with the two most traditionally cultured aquaponic species, tilapia and catfish. Most of these novel species are already known to conventional aquaculture systems. For instance, in the last years, the production of tambaqui and pacu in ponds or cages has been widespread in the American continent (Valladão et al. 2018), as mentioned in the previous species descriptions. However, only a few studies have been carried out to evaluate their production in aquaponics. The reported aquaponics production of South American species was only performed in coupled systems. Among these species, pacu and jundia have been the most evaluated in aquaponics, and encouraging growth results were found in all studies (Pinho et al. 2017; Rocha et al. 2017; Araújo 2015).

Matching the physical-chemical parameters of the water that is tolerated by the respective fish species to those required by plants is a key factor in coupled systems. The optimal ranges or the maximum levels of these parameters for the suggested fish species were reviewed in this study (Table 1). In general, fish that tolerate a wide range of water parameters are desirable. More specifically, species are highly suitable for these system designs when (1) they can be reared in water with $\mathrm{pH}$ between 5.5 and 6.5 , since this is the range when nutrients are mostly available to plants (Resh 2012), and (2) they tolerate high levels of nitrate, which is crucial in determining the plant-growing area (Goddek et al. 2016). Given these characteristics, jundia stands out most among the South American species, although the physiological ability of 
tambaqui to tolerate large $\mathrm{pH}$ variations and its better growth in acidic water (Aride et al. 2007) also make it an outstanding species for coupled aquaponics production. The resistance of tambaqui to an acidic environment is due to its adaption to the wide $\mathrm{pH}$ range of the Amazonian rivers, home of this species. This fish is naturally found in the Negro River ( $\mathrm{pH}$ 4.7) and Solimoes/Amazonas River ( $\mathrm{pH} \sim 6.8$ ) (da Silva et al. 2013). It is important to highlight that the values in Table 1 were obtained from experimental results in different production systems that, in some cases, did not evaluate specifically the parameters mentioned and only reported them as excellent for the species. Because of this, we assert that research designed to investigate the $\mathrm{pH}$ toleration level of each species in RAS or aquaponics should be encouraged. New results may show that these species tolerate wider ranges of water parameters and, consequently, have even more potential for production in aquaponics.

For decoupled aquaponics systems or other aquaponics systems where fish is a relevant product, fish zootechnical performance must be considered. Reports of RAS production for all reviewed species are available. However, most of them were cultivated under experimental conditions that did not explore their productive potential. Pacu, snook and tambaqui stand out as the species that can be grown with the highest stocking density. The density for pacu rearing $\left(75 \mathrm{~kg} \mathrm{~m}^{-3}\right)$ is higher than that commonly found for tilapia $\left(70 \mathrm{~kg} \mathrm{~m}^{-3}\right)$ in aquaponics. On the other hand, catfish (Clarias gariepinus) culture density in aquaponics is significantly superior (300 $\mathrm{kg} \mathrm{m}^{-3}$, Baganz et al. 2020) as it is a rustic species and tolerates poor rearing conditions when compared to the other reviewed species. The production of jundia and yellowtail lambari is usually carried out in densities below $20 \mathrm{~kg} \mathrm{~m}^{-3}$, three times lower than for tilapia. Research focused on increasing densities should be developed in order to make these species economically competitive in future RAS and aquaponics production. The FCR of lambari is the most desired among the species, ranging from 1.1 to 1.5 . However, all the reviewed species show similar FCR and, because protein ingredients are the most expensive components of the diets, it is important to take into account the protein requirement of each species. In this sense, the lowest cost of feed would be for omnivore species, especially tambaqui, because it is the one with the lowest protein requirement. In contrast, although the FCR range for snook culture is comparable to the other species, it is a carnivorous fish and the amount of protein required in the diet would increase production costs.

The choice of fish species will depend on the demand and characteristics of the market where the aquaponics system will be located. For example, if the aim of production is to supply restaurants with differentiated fish cuts, the rearing of tambaqui and/or pacu should be considered. If the local market demands fish as a snack, yellowtail lambari will be the best option. For the supply of fillets, the snook can supply the high-end fish market while the jundia will be a more popular alternative. The market value and production cost of each species must also be taken into account. Table 2 shows the fish sale price according to CEAGESP, which is the biggest food warehouse in Latin America and sells fish from fisheries and aquaculture. The price of snook is four times higher than the others; however, its production is not yet at a commercial scale and there is no information on such costs. On the other hand, the sale price of the other novel species is higher or, at least, competitive in relation to the price of the traditional species. It should be noted that these prices are regional and will change according to the local market. Moreover, all these factors mentioned will influence the operational and economic planning of production.

Nutritious healthy food is usually understood as having low fat and high protein content (Jim et al. 2017). In this sense, the protein and fat content of the proposed South American species is more desirable than that reported for catfish, with the exception of pacu flesh which 
has $8.4 \%$ fat compared to $7.6 \%$ fat in catfish. On the other hand, protein content in tilapia fillet is surpassed only by snook. In addition to high muscle protein and low fat content, snook can offer an amount of $n$-3 highly unsaturated fatty acids (HUFA) higher than all other reviewed species. Freshwater tropical fish, generally, present lower concentrations of $n$-3 HUFA when compared to cold water marine fish. This fact encouraged research into $n$-3 HUFA supplementation in diets for freshwater fish grown in intensive systems (Stoneham et al. 2018), and this approach may be applicable to aquaponics systems in the future. In contrast to snook, the reported protein composition of yellowtail lambari is low. Although the protein content was analysed in different types of samples, that is, in the fillet for snooks and whole fish for lambari, they indicate the composition of the edible food. In this way, yellowtail lambari, as it is consumed, provides the least protein of the South American species. Nevertheless, it should be considered an important food for human consumption, since lambari can be a source of minerals, vitamins and other nutrients for vulnerable populations (Fonseca et al. 2017; Fiedler et al. 2016) and its $n-3$ to $n-6$ ratio is similar to the reported values for the traditional aquaponics species, i.e. around 0.40 and 0.49 .

Aquaponics is not yet a well-represented food production system in South American countries (Emerenciano 2016). This may be related to the current high availability of fresh water and land in most of these countries, which results in the mistaken impression that incentives for sustainable aquaculture practices are not needed. Another relevant factor is the lack of political incentive, inspection or severe punishment for producers who degrade the environment (Azevedo et al. 2020). All these factors, in addition to the countries' current economic situation, result in low investment in advanced technologies for aquaculture and the predominance of production in conventional methods (ponds and cages). However, the growing need for food production technologies that minimize the use of natural resources should become the driving force for adopting more sustainable methods of production and stimulate the growth of aquaponics in these countries. At this point, knowing the feasibility of producing native fish species as well as encouraging research focused on evaluating the suitability of different regional species of plants in aquaponics is important. Until that happens, the information provided in this review will be useful to increase the variety of products and the satisfaction of different markets in countries where aquaponics is already a reality or is starting to grow.

\section{Conclusions}

The brief description of the South American species and the comparison with the traditionally reared species show that the five considered species (jundia, pacu, tambaqui, lambari and snook) are suitable for aquaponics production. The degree of their suitability, however, will depend on the system design, i.e. coupled or decoupled systems, as well as the characteristics of the regional market. It is recommended that future research focuses on understanding the optimal or tolerable water parameters and productive management, e.g. density and feeding rate, for each of the five species considered in recirculating aquaculture systems. In addition, practical applications of these species in aquaponics and their economic feasibility should be encouraged. 
Acknowledgements The authors are especially grateful to Eduardo Antônio Sanches, Emerson Durigon, Eduardo Abimorad, Jenner Menezes and Flávio F. Ribeiro for the photos of the fish that illustrate this article.

Code availability Not applicable.

Funding This work is part of the research programme SUGI/Food-Water-Energy-Nexus "CITYFOOD”, which is partly financed by the São Paulo Research Foundation (FAPESP - project number 2017/50431-9) and the Netherlands Organisation for Scientific Research (NWO - project number 438-17-402). We also received financial support from FAPESP for the project 2019/02140-0, for the Ph.D. scholarship provided to Pinho SM (grants 2018/13235-0, 2019/21315-6) and David LH (grants 2018/20463-9, 2019/21703-6) and from CNPq/ Brazil for the fellowship (311108/2017-2) and Ph.D. scholarship (140838/2018-0) provided to Portella MC and Pinho SM, respectively.

Data availability Not applicable.

\section{Declarations}

Ethical statement No animal was used for the development of this paper.

Consent to participate Not applicable.

Consent for publication All authors consented with the publication.

Conflict of interest The authors declare no competing interests.

Open Access This article is licensed under a Creative Commons Attribution 4.0 International License, which permits use, sharing, adaptation, distribution and reproduction in any medium or format, as long as you give appropriate credit to the original author(s) and the source, provide a link to the Creative Commons licence, and indicate if changes were made. The images or other third party material in this article are included in the article's Creative Commons licence, unless indicated otherwise in a credit line to the material. If material is not included in the article's Creative Commons licence and your intended use is not permitted by statutory regulation or exceeds the permitted use, you will need to obtain permission directly from the copyright holder. To view a copy of this licence, visit http://creativecommons.org/licenses/by/4.0/.

\section{References}

Abreu MS, Giacomini ACVV, Koakoski G, Piato AL, Barcellos LJG (2016) Evaluating “anxiety” and social behavior in jundiá (Rhamdia quelen). Physiol Behav 160:59-65. https://doi.org/10.1016/j.physbeh.2016.04.003

AEAARP (2015) Aquaponia com lambaris. Painel 5-9. https://www.aeaarp.org.br/upload/revista/ 20170711150244painel-244.pdf. Accessed 20 May 2020

Akinwole AO, Faturoti EO (2007) Biological performance of African Catfish (Clarias gariepinus) cultured in recirculating system in Ibadan. Aquac Eng 36:18-23. https://doi.org/10.1016/j.aquaeng.2006.05.001

Almeida FL, Lopes JS, Crescencio R, Izel ACU, Chagas EC, Boijink C (2016) Early puberty of farmed tambaqui (Colossoma macropomum): possible influence of male sexual maturation on harvest weight. Aquaculture 452:224-232. https://doi.org/10.1016/j.aquaculture.2015.10.031

Alvarez-Lajonchère L, Tsuzuki MY (2008) A review of methods for Centropomus spp. (snooks) aquaculture and recommendations for the establishment of their culture in Latin America. Aquac Res 39:684-700. https:// doi.org/10.1111/j.1365-2109.2008.01921.x

Araújo AF (2015) Integração de plantas com espécies nativas de peixes em sistema de aquaponia. Dissertation, Federal University of Santa Catarina

Araújo ES, de Melo NA, Lima da SE, et al (2017) Construção de um sistema de aquaponia para a produção consorciada de tomate Itália (Solanun lycopersicum) e tambaqui (Colossoma macropomum). In: VI Congresso Latino-Americano de Agroecologia. Brasília, pp 1-6 
Aride PHR, Roubach R, Val AL (2007) Tolerance response of tambaqui Colossoma macropomum (Cuvier) to water pH. Aquac Res 38:588-594. https://doi.org/10.1111/j.1365-2109.2007.01693.x

Ariede RB, Freitas MV, Agudelo JFG, Borges CHS, Lira LVG, Yoshida GM, Pilarski F, Yáñez JM, Hashimoto DT (2020) Genetic (co)variation between resistance to Aeromonas hydrophila and growth in tambaqui (Colossoma macropomum). Aquaculture 523:735225. https://doi.org/10.1016/j.aquaculture.2020.735225

Azevedo SG, Sequeira T, Santos M, Nikuma D (2020) Climate change and sustainable development: the case of Amazonia and policy implications. Environ Sci Pollut Res 27:7745-7756

Baganz G, Baganz D, Staaks G et al (2020) Profitability of multi-loop aquaponics: year-long production data, economic scenarios and a comprehensive model case. Aquac Res Are 14610. https://doi.org/10.1111/are.14610

Baldisserotto B (2008) Piscicultura continental no Rio Grande do Sul: situação atual, problemas e perspectivas para o futuro. Ciência Rural 39:291-299. https://doi.org/10.1590/S0103-84782008005000046

Barbas LAL, de Araújo ERL, Torres MF, Maltez LC, Garcia LO, Heinzmann BM, Sampaio LA (2020) Stress relieving potential of two plant-based sedatives in the transport of juvenile tambaqui Colossoma macropomum. Aquaculture 520:734681. https://doi.org/10.1016/j.aquaculture.2019.734681

Barbosa AC, Ferreira P d MF, Souza RN d (2009) Avaliação da taxa metabólica do Tambaqui (Colossoma macropomum) e da tilápia do nilo (Oreochromis niloticus). Rev Bras Eng Pesca 4:46-55. https://doi.org/10. 18817/REPESCA.V4I2.111

Barcellos LJG, Wassermann GF, Scott AP, Woehl VM, Quevedo RM, Ittzés I, Krieger MH, Lulhier F (2001) Steroid profiles in cultured female jundiá, the siluridae Rhamdia quelen (Quoy and Gaimard, Pisces teleostei), during the first reproductive cycle. Gen Comp Endocrinol 121:325-332. https://doi.org/10. 1006/gcen.2001.7603

Barcellos LJG, Kreutz LC, Quevedo RM, da Rosa JGS, Koakoski G, Centenaro L, Pottker E (2009) Influence of color background and shelter availability on jundiá (Rhamdia quelen) stress response. Aquaculture 288:5156. https://doi.org/10.1016/j.aquaculture.2008.11.002

Battisti EK, Marasca S, Durigon EG, Villes VS, Schneider TLS, Uczay J, Peixoto NC, Lazzari R (2017) Growth and oxidative parameters of Rhamdia quelen fed dietary levels of vitamin A. Aquaculture 474:11-17. https:// doi.org/10.1016/j.aquaculture.2017.03.025

Battisti EK, Rabaioli A, Uczay J, Sutili FJ, Lazzari R (2020) Effect of stocking density on growth, hematological and biochemical parameters and antioxidant status of silver catfish (Rhamdia quelen) cultured in a biofloc system. Aquaculture 524:735213. https://doi.org/10.1016/j.aquaculture.2020.735213

Bittencourt F, Feiden A, Signor AA, Boscolo WR, Lorenz EK, Maluf MLF (2010) Densidade de estocagem e parâmetros eritrocitários de pacus criados em tanques-rede. Rev Bras Zootec 39:2323-2329

Bittencourt LS, Silva URL, Silva LMA, Dias MT (2014) Impact of the invasion from Nile tilapia on natives Cichlidae species in tributary of Amazonas River, Brazil. Biota Amaz 4:88-94. https://doi.org/10.18561/ 2179-5746/biotaamazonia.v4n3p88-94

Bosma RH, Lacambra L, Landstra Y, Perini C, Poulie J, Schwaner MJ, Yin Y (2017) The financial feasibility of producing fish and vegetables through aquaponics. Aquac Eng 78:146-154. https://doi.org/10.1016/j.aquaeng. 2017.07.002

Campos JL, Ono EA, Istchuk PI (2015) Tambaqui: Considerações sobre a cadeia de produção e o preço. Panor. da Aquicultura 25:42-45

Carneiro PCF, Morais CARS, Nunes MUC et al (2015) Produção integrada de peixes e vegetais em aquaponia. EMBRAPA Tabuleiros Costeiros, Aracaju

Cartonilho MM, de Jesus RS (2011) Qualidade de cortes congelados de tambaqui cultivado. Pesqui Agropecu Bras 46:344-350. https://doi.org/10.1590/S0100-204X2011000400002

CEAGESP (2020) Cotações. In: Preços no Atacado. www.ceagesp.gov.br/entrepostos/servicos/cotacoes/\#cotacao. Accessed 26 May 2020

Cerqueira VR (2010) Cultivo do robalo-peva (Centropomus parallelus). In: Baldisserotto B, Gomes LC (eds). Espécies Nativas para Piscicultura no Brasil, 2nd edn. UFSM, Santa Maria, pp 489-520

Coldebella IJ, Neto JR, Mallmann CA, Veiverberg CA, Bergamin GT, Pedron FA, Ferreira D, Barcellos LJG (2011) The effects of different protein levels in the diet on reproductive indexes of Rhamdia quelen females. Aquaculture 312:137-144. https://doi.org/10.1016/j.aquaculture.2010.12.021

Correia D, David LHC, Pinho SM, Costa-Filho J, Emerenciano MGC, Mello GL (2018) Performance of fat snook juveniles reared at different temperatures. Acta Sci - Anim Sci 40:40. https://doi.org/10.4025/actascianimsci. v40i1.39766

Cruz T, Oliveira W, Santos A (2015) Efeito da associação piscicultura-hidroponia sobre a qualidade da água e desempenho de tambaquis. $11^{\circ}$ Scientific Seminar of UFT 7

Cunha JA, de Ávila SC, Fausto VP et al (2018) The antibacterial and physiological effects of pure and nanoencapsulated Origanum majorana essential oil on fish infected with Aeromonas hydrophila. Microb Pathog 124:116-121. https://doi.org/10.1016/j.micpath.2018.08.040 
da Costa OTF, Dias LC, Malmann CSY et al (2019) The effects of stocking density on the hematology, plasma protein profile and immunoglobulin production of juvenile tambaqui (Colossoma macropomum) farmed in Brazil. Aquaculture 499:260-268. https://doi.org/10.1016/j.aquaculture.2018.09.040

da Silva AMD, de C Gomes L, Roubach R (2007) Growth, yield, water and effluent quality in ponds with different management during tambaqui juvenile production. Pesqui Agropecuária Bras 42:733-740. https:// doi.org/10.1590/S0100-204X2007000500017

da Silva MDSR, Miranda SÁF, Domingos RN et al (2013) Classificação dos rios da Amazônia: uma estratégia para preservação desses recursos. Holos Environ 13:163. https://doi.org/10.14295/holos.v13i2.7344

da Silva GS, Matos LV de, da S Freitas JO et al (2019) Gene expression, genotoxicity, and physiological responses in an Amazonian fish, Colossoma macropomum (Cuvier 1818), exposed to Roundup® and subsequent acute hypoxia. Comp Biochem Physiol Part - C Toxicol Pharmacol 222:49-58. https://doi.org/ 10.1016/j.cbpc.2019.04.010

Dalsgaard J, Lund I, Thorarinsdottir R, Drengstig A, Arvonen K, Pedersen PB (2013) Farming different species in RAS in Nordic countries: current status and future perspectives. Aquac Eng 53:2-13. https://doi.org/10. 1016/j.aquaeng.2012.11.008

Danner RI, Mankasingh U, Anamthawat-Jonsson K, Thorarinsdottir RI (2019) Designing aquaponic production systems towards integration into greenhouse farming. Water (Switzerland) 11:2123. https://doi.org/10.3390/w11102123

Dantas DP, Flickinger DL, Costa GA, Batlouni SR, Moraes-Valenti P, Valenti WC (2020) Technical feasibility of integrating Amazon river prawn culture during the first phase of tambaqui grow-out in stagnant ponds, using nutrient-rich water. Aquaculture 516:734611. https://doi.org/10.1016/j.aquaculture.2019.734611

David LHC, da Rocha RC, Piazza TB et al (2019a) Influência da densidade de estocagem no desempenho zootécnico do pacu durante a pré-engorda. Arq Ciên Mar 52:50-56

David LHC, Pinho SM, Correia D, Tsuzuki MY, Emerenciano MGC, Mello GL (2019b) Desempenho zootécnico e rendimento de filé do robalo-flecha alimentado com diferentes dietas comerciais. Arq Ciências Mar 52:69-80

de Castro F, Van Dijk P, Hogenboom B (2014) The extraction and conservation of natural resources in South America. Recent Trends and Challenges. CEDLA, Amsterdam

de Moraes AV, de O Pereira M, Moraes KN et al (2018) Autochthonous probiotic as growth promoter and immunomodulator for Astyanax bimaculatus cultured in water recirculation system. Aquac Res 49:28082814. https://doi.org/10.1111/are.13743

De Smet S (2012) Meat, poultry, and fish composition: strategies for optimizing human intake of essential nutrients. Anim Front 2:10-16. https://doi.org/10.2527/af.2012-0057

Delaide B, Monsees H, Gross A, Goddek S (2019) Aerobic and anaerobic treatments for aquaponic sludge reduction and mineralisation. In: Goddek S, Joyce A, Kotzen B, Burnell GM (eds) Aquaponics food production systems, 1st edn. Springer International Publishing, Cham, pp 247-266. https://doi.org/10. 1007/978-3-030-15943-6 10

dos Santos VB, de Oliveira MWM, Salomão RAS, Santos RS, de Paula TG, Silva MDP, Mareco EA (2017) Influence of temperature and exercise on growth performance, muscle, and adipose tissue in pacus (Piaractus mesopotamicus). J Therm Biol 69:221-227. https://doi.org/10.1016/j.jtherbio.2017.08.004

El-Sayed AFM (2006) Tilapia culture. CABI, Wallingford

Emerenciano M (2016) Aquaponics in South America: state of art and perspectives. International Conference "Aquaponics Research Matters, Slovenia, p 80

Espinal CA, Matulić D (2019) Recirculating aquaculture technologies. In: Goddek S, Joyce A, Kotzen B, Burnell GM (eds) Aquaponics food production systems, 1st edn. Springer International Publishing, Cham, pp 35-76. https://doi.org/10.1007/978-3-030-15943-6_3

FAO (2016) Planning for aquaculture diversification: the importance of climate change and other drivers. FAO Technical Workshop, 23-25 June 2016. FAO, Rome

FAO (2018a) The state of world fisheries and aquaculture 2018: Meeting the sustainable development goals. FAO, Rome

FAO (2018b) Visión general del sector acuícola nacional - Argentina. http://www.fao.org/fishery/countrysector/ naso_argentina/es. Accessed 27 Apr 2020

FAO (2019) Field guide to the culture of tambaqui (Colossoma macropomum, Cuvier, 1816). Fisheries and Aquaculture Technical Paper, Rome

FAO (2020) FAOSTAT. Food Agric. Organ., United Nations http://www.fao.org/faostat/en/\#data. Accessed 27 Apr 2020

FatSecret (2020) Tambaqui. https://www.fatsecret.com.br/calorias-nutrição/genérico/tambaqui. Accessed $10 \mathrm{Mar}$ 2020 
Fiedler JL, Lividini K, Drummond E, Thilsted SH (2016) Strengthening the contribution of aquaculture to food and nutrition security: the potential of a vitamin A-rich, small fish in Bangladesh. Aquaculture 452:291-303. https://doi.org/10.1016/j.aquaculture.2015.11.004

FIGIS-FAO (2020) Global Production Statistics 1950-2018. http://www.fao.org/figis/servlet/SQServlet?file=/ usr/local/tomcat/8.5.16/figis/webapps/figis/temp/hqp_5124421347169482612.xml\&outtype=html. Accessed 27 Apr 2020

Filho AAM, de Oliveira H, dos Santos RC (2013) Omega-6/Omega-3 and PUFA/SFA in Colossoma macropomum Grown in Roraima, Brazil. Orbital-The Electron J Chem 5:30-34

Fonseca T, Costa-Pierce BA, Valenti WC (2017) Lambari aquaculture as a means for the sustainable development of rural communities in Brazil. Rev Fish Sci Aquac 25:316-330. https://doi.org/10.1080/23308249.2017.1320647

Furuya WMM, Michelato M, Da Silva LCR et al (2008) Fitase em rações para Juvenis de Pacu (Piaractus mesopotamicus). Bol Inst Pesca 34:489-496

Furuya VB, Furuya WM, Michelato M, et al (2013) Composição proximal e perfil de ácidos graxos do lambarido-rabo-vermelho (Astyanax fasciatus) de diferentes classes de peso. Rev bras saúde prod anim 14:820-830. https://doi.org/10.1590/S1519-99402013000400020

Gallego V, Cavalcante SS, Fujimoto RY, Carneiro PCF, Azevedo HC, Maria AN (2017) Fish sperm subpopulations: changes after cryopreservation process and relationship with fertilization success in tambaqui (Colossoma macropomum). Theriogenology 87:16-24. https://doi.org/10.1016/j.theriogenology.2016.08.001

Garutti V (1995) Revisão taxonômica dos Astyanax (Pisces, Characidae), com mancha umeral ovalada e mancha no pedúnculo caudal, estendendo-se à extremidade dos raios caudais medianos, das bacias do Paraná. Universidade Estadual Paulista, São Francisco e Amazônica

Garutti V (2003) Piscicultura Ecologica. Editora UNESP, São Paulo

Garutti V, Britski H (2000) Descrição de uma espécie nova de Astyanax (Teleostei: Characidae) da bacia do alto Rio Paraná e considerações sobre as demais espécies do gênero na bacia. Comunicações do Museu de Ciencias da PUCRS Série Zoologia 13:65-88

Goddek S, Keesman KJ (2018) The necessity of desalination technology for designing and sizing multi-loop aquaponics systems. Desalination 428:76-85. https://doi.org/10.1016/j.desal.2017.11.024

Goddek S, Körner O (2019) A fully integrated simulation model of multi-loop aquaponics: a case study for system sizing in different environments. Agric Syst 171:143-154. https://doi.org/10.1016/j.agsy.2019.01.010

Goddek S, Delaide B, Mankasingh U, Ragnarsdottir K, Jijakli H, Thorarinsdottir R (2015) Challenges of sustainable and commercial aquaponics. Sustain 7:4199-4224. https://doi.org/10.3390/su7044199

Goddek S, Espinal CA, Delaide B et al (2016) Navigating towards decoupled aquaponic systems: a system dynamics design approach. Water (Switzerland) 8(1):29. https://doi.org/10.3390/W8070303

Goddek S, Joyce A, Kotzen B, Dos-Santos M (2019a) Aquaponics and global food challenges. In: Goddek S, Joyce A, Kotzen B, Burnell GM (eds) Aquaponics Food production systems, 1st edn. Springer International Publishing, Cham, pp 3-17. https://doi.org/10.1007/978-3-030-15943-6_1

Goddek S, Joyce A, Wuertz S, Körner O, Bläser I, Reuter M, Keesman KJ (2019b) Decoupled aquaponics systems. In: Goddek S, Joyce A, Kotzen B, Burnell GM (eds) Aquaponics food production systems, 1st edn. Springer International Publishing, Cham, pp 201-229. https://doi.org/10.1007/978-3-030-15943-6_8

Goes MD, dos Reis Goes ES, Ribeiro RP et al (2017) Natural and artificial spawning strategies with fresh and cryopreserved semen in Rhamdia quelen: reproductive parameters and genetic variability of offspring. Theriogenology 88:254-263.e3. https://doi.org/10.1016/j.theriogenology.2016.09.029

Golan M, Levavi-Sivan B (2014) Artificial masculinization in tilapia involves androgen receptor activation. Gen Comp Endocrinol 207:50-55. https://doi.org/10.1016/j.ygcen.2014.04.026

Gomes LC, Golombieski JI, ARC G, Baldisserotto B (2000) Biologia do jundiá Rhamdia quelen (Teleostei, Pimelodidae). Ciência Rural 30:179-185. https://doi.org/10.1590/s0103-84782000000100029

Gomes LC, Simões LN, Araujo-Lima CARM (2010) Tambaqui (Colossoma macropomum). In: Baldisserotto B, Gomes LC (eds) Espécies Nativas para Piscicultura no Brasil, 2nd edn. UFSM, Santa Maria, pp 589- 606

Gominho-Rosa MC, Rodrigues APO, Mattioni B et al (2015) Comparison between the omnivorous jundiá catfish (Rhamdia quelen) and Nile tilapia (Oreochromis niloticus) on the utilization of dietary starch sources: digestibility, enzyme activity and starch microstructure. Aquaculture 435:92-99. https://doi.org/10.1016/j. aquaculture.2014.09.035

Gonçalves LU, Parisi G, Bonelli A, Sussel FR, Viegas EMM (2014) The fatty acid compositions of total, neutral and polar lipids in wild and farmed lambari (Astyanax altiparanae) (Garutti \& Britski, 2000) broodstock. Aquac Res 45:195-203. https://doi.org/10.1111/j.1365-2109.2012.03215.x

Gracia-López V, Rosas-Vázquez C, Brito-Pérez R (2006) Effects of salinity on physiological conditions in juvenile common snook Centropomus undecimalis. Comp Biochem Physiol - A Mol Integr Physiol 145: 340-345. https://doi.org/10.1016/j.cbpa.2006.07.008

Ha N, Jesus GFA, Gonçalves AFN, de Oliveira NS, Sugai JK, Pessatti ML, Mouriño JLP, el Hadi Perez Fabregat T (2019) Sardine (Sardinella spp.) protein hydrolysate as growth promoter in South American catfish 
(Rhamdia quelen) feeding: productive performance, digestive enzymes activity, morphometry and intestinal microbiology. Aquaculture 500:99-106. https://doi.org/10.1016/j.aquaculture.2018.10.004

Hampf AC, Stella T, Berg-Mohnicke M, Kawohl T, Kilian M, Nendel C (2020) Future yields of double-cropping systems in the Southern Amazon, Brazil, under climate change and technological development. Agric Syst 177:102707. https://doi.org/10.1016/j.agsy.2019.102707

Hashimoto DT, Mendonça FF, Senhorini JA, de Oliveira C, Foresti F, Porto-Foresti F (2011) Molecular diagnostic methods for identifying Serrasalmid fish (Pacu, Pirapitinga, and Tambaqui) and their hybrids in the Brazilian aquaculture industry. Aquaculture 321:49-53. https://doi.org/10.1016/j.aquaculture.2011.08.018

Hashimoto DT, Senhorini JA, Foresti F, Porto-Foresti F (2012) Interspecific fish hybrids in Brazil: management of genetic resources for sustainable use. Rev Aquac 4:108-118. https://doi.org/10.1111/j.1753-5131.2012. 01067.x

Hauville MR, Rhody NR, Resley MJ, Bell JG, Main KL, Migaud H (2015) Comparative study of lipids and fatty acids in the liver, muscle, and eggs of wild and captive common snook broodstock. Aquaculture 446:227235. https://doi.org/10.1016/j.aquaculture.2015.04.026

Hilbig CC, Boscolo WR, Feiden A, Dieterich F, Lorenz EK, Zaminhan M (2012) Feeding rate for pacu reared in net cages. Rev Bras Zootec 41:1570-1575. https://doi.org/10.1590/S1516-35982012000700003

IBGE (2018) Produção da aquicultura, por tipo de produto. IBGE. https://sidra.ibge.gov.br/tabela/3940. Accessed 27 Apr 2020

Ibrahim M, Castro F, Oliveira W (2015) Qualidade da água e desempenho de juvenis de tambaqui criados em sistema de aquaponia. $11^{\circ}$ Scientific Seminar of UFT 7

Jatobá A, Silva BC (2015) Densidade de estocagem na produção de juvenis de duas espécies de lambaris em sistema de recirculação. Arq Bras Med Vet Zootec 67:1469-1474

Jim F, Garamumhango P, Musara C (2017) Comparative analysis of nutritional value of Oreochromis niloticus (Linnaeus), Nile tilapia, meat from three different ecosystems. J Food Qual 2017:1-8. https://doi.org/10. $1155 / 2017 / 6714347$

Jomori RK, Carneiro DJ, Malheiros EB, Portella MC (2003) Growth and survival of pacu Piaractus mesopotamicus (Holmberg, 1887) juveniles reared in ponds or at different initial larviculture periods indoors. Aquaculture 221:277-287. https://doi.org/10.1016/S0044-8486(03)00069-3

Joshi HD, Tiwari VK, Gupta S, Sharma R, Lakra WS, Sahoo U (2019) Application of nanotechnology for the production of masculinized Tilapia, Oreochromis niloticus (Linnaeus, 1758). Aquaculture 511:232-243. https://doi.org/10.1016/j.aquaculture.2019.734206

Joyce A, Goddek S, Kotzen B, Wuertz S (2019) Aquaponics: closing the cycle on limited water, land and nutrient resources. In: Goddek S, Joyce A, Kotzen B, Burnell GM (eds) Aquaponics food production systems, 1st edn. Springer International Publishing, Cham, pp 19-34. https://doi.org/10.1007/978-3-03015943-6_2

Júnior LPG, Sousa JGS, Selvatici PDC et al (2017) Metionina+cistina digestível para juvenis de tambaqui. Arq Bras Med Vet Zootec 69:711-717. https://doi.org/10.1590/1678-4162-9052

Kavalco KF (2008) Estudos evolutivos no gênero Astyanax (Pisces, Characidae). Dissertation, São Paulo University

Knaus U, Palm HW (2017) Effects of the fish species choice on vegetables in aquaponics under spring-summer conditions in northern Germany (Mecklenburg Western Pomerania). Aquaculture 473:62-73. https://doi.org/ 10.1016/j.aquaculture.2017.01.020

König B, Janker J, Reinhardt T, Villarroel M, Junge R (2018) Analysis of aquaponics as an emerging technological innovation system. J Clean Prod 180:232-243. https://doi.org/10.1016/j.jclepro.2018.01.037

Kulawik P, Özoğul F, Glew RH (2013) Quality properties, fatty acids, and biogenic amines profile of fresh tilapia stored in ice. J Food Sci 78:S1063-S1068. https://doi.org/10.1111/1750-3841.12149

Kyaw TY, Ng AK (2017) Smart aquaponics system for urban farming, Energy Procedia 143:342-347. https:// doi.org/10.1016/j.egypro.2017.12.694

Lazzari R, Neto JR, Corrêia V et al (2011) Densidade de estocagem no crescimento, composição e perfil lipídico corporal do jundiá. Ciência Rural 41:712-718

Lennard W, Goddek S (2019) Aquaponics: the basics. In: Goddek S, Joyce A, Kotzen B, Burnell GM (eds) Aquaponics food production systems, 1st edn. Springer International Publishing, Cham, pp 113-143. https:// doi.org/10.1007/978-3-030-15943-6_5

Liebl F, Amaral H, Garcia S et al (2016) Desempenho de juvenis de robalo-flecha e robalo-peva submetidos a diferentes densidades de estocagem em água doce. Bol Inst Pesca 42:145-155. https://doi.org/10.5007/16782305.2016v42n1p145

Lima JF, Montagner D, Duarte SS et al (2019) Recirculating system using biological aerated filters on tambaqui fingerling farming. Pesqui Agropecuária Bras 54:54. https://doi.org/10.1590/s1678-3921.pab2019.v54. 00294 
Lira LVG, Kuradomi RY, Gonçalves TS et al (2018) Astyanax altiparanae ovarian maturation after spawning in water recycling systems. Bol Inst Pesca 44:207. https://doi.org/10.20950/1678-2305.2018.44.4.207

Liu CLC, Kuchma O, Krutovsky KV (2018) Mixed-species versus monocultures in plantation forestry: development, benefits, ecosystem services and perspectives for the future. Glob Ecol Conserv 15:e00419

Love DC, Fry JP, Genello L, Hill ES, Frederick JA, Li X, Semmens K (2014) An international survey of aquaponics practitioners. PLoS One 9:e102662. https://doi.org/10.1371/journal.pone.0102662

Love DC, Fry JP, Li X, Hill ES, Genello L, Semmens K, Thompson RE (2015) Commercial aquaponics production and profitability: findings from an international survey. Aquaculture 435:67-74. https://doi.org/ 10.1016/j.aquaculture.2014.09.023

Lucena CAS, Soares HG (2016) Review of species of the Astyanax bimaculatus "caudal peduncle spot" subgroup sensu Garutti \& Langeani (Characiformes, Characidae) from the rio la Plata and rio São Francisco drainages and coastal systems of southern Brazil and Uruguay. Zootaxa 4072:101-125

Machado-Neto R, Moretti DB, Nordi WM, da Cruz TMP, Cyrino JEP (2016) Growth performance of juvenile pacu (Piaractus mesopotamicus) and dourado (Salminus brasiliensis) fed with lyophilized bovine colostrum. Aquac Res 47:3551-3557. https://doi.org/10.1111/are.12805

Madsen H, Thien PC, Nga HTN, Clausen JH, Dalsgaard A, Murrell KD (2015) Two-year intervention trial to control of fish-borne zoonotic trematodes in giant gourami (Osphronemus goramy) and striped catfish (Pangasianodon hypophthalmus) in nursery ponds in the Mekong Delta, Vietnam. Acta Trop 152:201-207. https://doi.org/10.1016/j.actatropica.2015.09.012

Maffezzolli G, Nuñer APO (2006) Crescimento de alevinos de jundiá, Rhamdia quelen (Pisces, Pimelodidae), em diferentes concentrações de oxigênio dissolvido. Acta Sci Biol Sci 28. https://doi.org/10.4025/ actascibiolsci.v28i1.1057

Mapenzi LL, Shimba MJ, Moto EA, Maghembe RS, Mmochi AJ (2020) Heavy metals bio-accumulation in tilapia and catfish species in Lake Rukwa ecosystem Tanzania. J Geochem Explor 208:106413. https://oi. org/10.1016/j.gexplo.2019.106413

Maria AN, Carvalho ACM, Araújo RV, Santos JP, Carneiro PCF, Azevedo HC (2015) Use of cryotubes for the cryopreservation of tambaqui fish semen (Colossoma macropomum). Cryobiology 70:109-114. https://doi. org/10.1016/j.cryobiol.2015.02.004

Martins P (2017) Aquaponia, uma novidade na educação ambiental. Ambient sustentable Rev científica galegolusófona. Educ Ambient I:101-106. https://doi.org/10.17979/ams.2017.23-24.0.3369

Martins CIM, Eding EH, Verdegem MCJ, Heinsbroek LTN, Schneider O, Blancheton JP, d'Orbcastel ER, Verreth JAJ (2010) New developments in recirculating aquaculture systems in Europe: a perspective on environmental sustainability. Aquac Eng 43:83-93. https://doi.org/10.1016/j.aquaeng.2010.09.002

Mchunu N, Lagerwall G, Senzanje A (2018) Aquaponics in South Africa: results of a national survey. Aquac Rep 12:12-19. https://doi.org/10.1016/j.aqrep.2018.08.001

Megbowon I, Mojekwu TO (2014) Tilapia sex reversal using methyl testosterone (MT) and its effect on fish, man and environment. Biotechnology (Faisalabad) 13:213-216. https://doi.org/10.3923/biotech.2014.213.216

Mello GL, Jerônimo GT, Tancredo KR et al (2015) Desenvolvimento e estado de saúde de Centropomus undecimalis parasitado por Rhabdosynochus rhabdosynochus (Monogenea) sob diferentes condições de salinidade e temperatura. Rev Bras Parasitol Vet 24:350-356. https://doi.org/10.1590/S1984-29612015062

Meyer G, Fracalossi DM (2004) Protein requirement of jundia fingerlings, Rhamdia quelen, at two dietary energy concentrations. Aquaculture 240:331-343. https://doi.org/10.1016/j.aquaculture.2004.01.034

Michelotti BT, Passini G, Carvalho C, Salbego J, Mori NC, Rodrigues RV, Baldisserotto B, Cerqueira VR (2018) Growth and metabolic parameters of common snook juveniles raised in freshwater with different water hardness. Aquaculture 482:31-35. https://doi.org/10.1016/j.aquaculture.2017.08.029

Michelotti BT, Mori NC, Magnotti CCF, Heinzmann BM, Almeida APG, Cerqueira VR, Baldisserotto B (2020) Citral as food additive for common snook-zootechnical parameters and digestive enzymes. Cienc Rural 50. https://doi.org/10.1590/0103-8478cr20190577

Monsees H, Kloas W, Wuertz S (2017) Decoupled systems on trial: eliminating bottlenecks to improve aquaponic processes. PLoS One 12:e0183056. https://doi.org/10.1371/journal.pone.0183056

Ng WK, Lim PK, Boey PL (2003) Dietary lipid and palm oil source affects growth, fatty acid composition and muscle $\alpha$-tocopherol concentration of African catfish, Clarias gariepinus. Aquaculture 215:229-243. https:// doi.org/10.1016/S0044-8486(02)00067-4

Nunes CS, Moraes G, Fabrizzi F et al (2013) Growth and hematology of pacu subjected to sustained swimming and fed different protein levels. Pesqui Agropecu Bras 48:645-650. https://doi.org/10.1590/S0100204X2013000600010

Nwanna LC, Oishi CA, Pereira-Filho M (2008) Use of phytase to improve the digestibility of alternative feed ingredients by Amazon tambaqui, Colossoma macropomum. ScienceAsia 34:353-360. https://doi.org/10. 2306/scienceasia1513-1874.2008.34.353 
Oishi CA, Nwanna LC, Pereira Filho M (2010) Optimum dietary protein requirement for Amazonian Tambaqui, Colossoma macropomum Cuvier, 1818, fed fish meal free diets. Acta Amaz 40:757-762. https://doi.org/10. 1590/s0044-59672010000400017

Oladimeji SA, Okomoda VT, Olufeagba SO, Solomon SG, Abol-Munafi AB, Alabi KI, Ikhwanuddin M, Martins CO, Umaru J, Hassan A (2020) Aquaponics production of catfish and pumpkin: comparison with conventional production systems. Food Sci Nutr 8:2307-2315. https://doi.org/10.1002/fsn3.1512

Owatari MS, Jesus GFA, de Melo Filho MES, Lapa KR, Martins ML, Mouriño JLP (2018) Synthetic fibre as biological support in freshwater recirculating aquaculture systems (RAS). Aquac Eng 82:56-62. https://doi. org/10.1016/j.aquaeng.2018.06.001

Padial AA, Agostinho Â, Azevedo-Santos VM, Frehse FA, Lima-Junior DP, Magalhães ALB, Mormul RP, Pelicice FM, Bezerra LAV, Orsi ML, Petrere-Junior M, Vitule JRS (2017) The "Tilapia Law" encouraging non-native fish threatens Amazonian River basins. Biodivers Conserv 26:243-246. https://doi.org/10.1007/s10531-016-1229-0

PAHO, Pan American Health Organization (2020) Eradicating hunger in Latin America and the Caribbean by 2030 is becoming increasingly unlikely. Worl Heal. Organ https:/www.paho.org/hq/index.php?option= com content\&view=article\&id=13790:eradicating-hunger-in-latin-america-and-the-caribbean-by-2030-isbecoming-increasingly-unlikely\&Itemid=1926\&lang=en. Accessed 27 Apr 2020

Pal J, Shukla BN, Maurya AK, Verma HO (2018) A review on role of fish in human nutrition with special emphasis to essential fatty acid. Int J Fish Acquat Stud 6:427-430

Palm HW, Knaus U, Appelbaum S, Strauch SM, Kotzen B (2019) Coupled aquaponics systems. In: Goddek S, Joyce A, Kotzen B, Burnell GM (eds) Aquaponics food production systems, 1st edn. Springer International Publishing, Cham, pp 163-199. https://doi.org/10.1007/978-3-030-15943-6 7

Pantoja-Lima J (2020) Avaliação do desempenho zootécnico de linhagens melhoradas de tambaqui Colossoma macropomum (Cuvier, 1818) na amazônia central. Rev Ibero-Americana Ciências Ambient 11:5

Passini G, Sterzelecki FC, de Carvalho CVA, Baloi MF, Naide V, Cerqueira VR (2018) 17 $\alpha$-Methyltestosterone implants accelerate spermatogenesis in common snook, Centropomus undecimalis, during first sexual maturation. Theriogenology 106:134-140. https://doi.org/10.1016/j.theriogenology.2017.10.015

Passini G, Carvalho CVA, Sterzelecki FC, Baloi MF, Cerqueira VR (2019) Spermatogenesis and steroid hormone profile in puberty of laboratory-reared common snook (Centropomus undecimalis). Aquaculture 500:622-630. https://doi.org/10.1016/j.aquaculture.2018.10.031

Paulino RR, Pereira RT, Fontes TV, Oliva-Teles A, Peres H, Carneiro DJ, Rosa PV (2018) Optimal dietary linoleic acid to linolenic acid ratio improved fatty acid profile of the juvenile tambaqui (Colossoma macropomum). Aquaculture 488:9-16. https://doi.org/10.1016/j.aquaculture.2018.01.014

Paz AL, da Silva JM, da Silva KMM, Val AL (2019) Protective effects of the fructooligosaccharide on the growth performance, hematology, immunology indicators and survival of tambaqui (Colossoma macropomum, Characiformes: Serrasalmidae) infected by Aeromonas hydrophila. Aquac Rep 15:100222. https://doi.org/10.1016/j.aqrep.2019.100222

Perazza CA, de Menezes JTB, Ferraz JBS, Pinaffi FLV, Silva LA, Hilsdorf AWS (2017) Lack of intermuscular bones in specimens of Colossoma macropomum: an unusual phenotype to be incorporated into genetic improvement programs. Aquaculture 472:57-60. https://doi.org/10.1016/j.aquaculture.2016.05.014

Piedras S, Moraes P, Pouey J (2004) Crescimento de juvenis de jundia (Rhamdia quelen), de acordo com a temperatura da água. Bol Inst Pesca 30:177-182

Pinho SM, Brol J, de Almeida EJ, de Mello GL, Jerônimo GT, Emerenciano MGC (2016) Effect of stocking density and vertical substrate addition on growth performance and health status of fat snook Centropomus parallelus. Aquaculture 457:73-78. https://doi.org/10.1016/j.aquaculture.2016.02.016

Pinho SM, de Mello GL, Fitzsimmons KM, Emerenciano MGC (2017) Integrated production of fish (pacu Piaractus mesopotamicus and red tilapia Oreochromis sp.) with two varieties of garnish (scallion and parsley) in aquaponics system. Aquac Int 26:99-112. https://doi.org/10.1007/s10499-017-0198-y

Poli MA, Schveitzer R, de Oliveira Nuñer AP (2015) The use of biofloc technology in a South American catfish (Rhamdia quelen) hatchery: effect of suspended solids in the performance of larvae. Aquac Eng 66:17-21. https://doi.org/10.1016/j.aquaeng.2015.01.004

Pope KL, Blankinship DR, Fisher M, Patiño R (2006) Status of the common snook (Centropomus undecimalis) in Texas. Tex J Sci 58:325-332

Portella M, Dabrowski K (2008) Diets, physiology, biochemistry and digestive tract development of freshwater fish larvae. In: Cyrino JEP (ed) Feeding and digestive functions in fishes, 1st edn. CRC Press, Boca Raton, pp 227-279. https://doi.org/10.1201/b10749-7

Portella MC, de J Leitão N, Takata R, Lopes TS (2012) Alimentação e nutrição de larvas. In: Fracalossi DM, Cyrino JEP (eds) Nutrição e alimentação de espécies de interesse para a aquicultura brasileira, 2nd edn. Aquabio, Florianópolis, pp 185-216 
Portella MC, Jomori RK, Leitão NJ, Menossi OCC, Freitas TM, Kojima JT, Lopes TS, Clavijo-Ayala JA, Carneiro DJ (2014) Larval development of indigenous South American freshwater fish species, with particular reference to pacu (Piaractus mesopotamicus): a review. Aquaculture 432:402-417

Porto-Foresti F, Castilho-Almeida RB, Foresti F (2010) Biologia e criação do lambari-do-rabo-amarelo (Astyanax altiparanae). In: Baldisserotto B, Gomes LC (eds) Espécies Nativas para Piscicultura no Brasil, 2nd edn. UFSM, Santa Maria, pp 101-115

Rakocy JE (2012) Aquaponics-integrating fish and plant culture. In: Aquaculture production systems. WileyBlackwell, Oxford, UK, pp 344-386

Rakocy JE, Bailey DS, Shultz RC, Thoman ES (2004) Update on tilapia and vegetable production in the UVI aquaponic system. New dimensions on farmed tilapia. Proceedings 6th International Symposium on tilapia in aquaculture. Manila, Philippines, pp 676-690

Rakocy JE, Masser MP, Losordo TM (2006) Recirculating aquaculture tank production systems: aquaponicsintegrating fish and plant culture. South Reg Aquac Cent. https://shareok.org/bitstream/handle/11244/ 319795/oksd_srac_454_2016-07.pdf?sequence=1. Accessed 20 June 2020

Ramos-Filho MM, Ramos MIL, Hiane PA, de Souza EMT (2008) Lipid profile of four species of fish from the Pantanal region of Mato Grosso do Sul. Ciênc Tecnol Aliment 28:361-365

Reis RE, Albert JS, Di Dario F et al (2016) Fish biodiversity and conservation in South America. J Fish Biol 89: 12-47. https://doi.org/10.1111/jfb.13016

Reis YS, Leite JLR, de Almeida CAL et al (2019) New insights into tambaqui (Colossoma macropomum) feeding behavior and digestive physiology by the self-feeding approach: effects on growth, dial patterns of food digestibility, amylase activity and gastrointestinal transit time. Aquaculture 498:116-122. https://doi. org/10.1016/j.aquaculture.2018.08.054

Resh HM (2012) Hydroponic food production: a definitive guidebook for the advanced home gardener and the commercial hydroponic grower, 7th edn. CRC Press

Rocha AF, Biazzetti Filho ML, Stech MR, Silva RP (2017) Lettuce production in aquaponic and biofloc systems with silver catfish Rhamdia quelen. Bol Inst Pesca 43:64-73. https://doi.org/10.20950/1678-2305.2017.64.73

Rodrigues APO (2014) Nutrition and feeding of tambaqui (Colossoma macropomum). Bol Inst Pesca 40:135-145

Rodrigues CG, Garcia BF, Verdegem M, Santos MR, Amorim RV, Valenti WC (2019) Integrated culture of Nile tilapia and Amazon river prawn in stagnant ponds, using nutrient-rich water and substrates. Aquaculture 503: 111-117. https://doi.org/10.1016/j.aquaculture.2018.12.073

Roriz GD, de VC Delphino MK, Gardner IA, Gonçalves VSP (2017) Characterization of tilapia farming in net cages at a tropical reservoir in Brazil. Aquac Rep 6:43-48. https://doi.org/10.1016/j.aqrep.2017.03.002

Ross LG (2000) Environmental physiology and energetics. In: Tilapias: Biology and Exploitation. Springer Netherlands, Dordrecht, pp 89-128

Sanches EG, Ostini S, da R Oliveira I, da S Serralheiro PC (2011) Cultivo do robalo-peva, Centropomus parallelus, em sistema de recirculação marinho. Arq Ciências Mar 44:40-46

Sanchez-Zamora A, Rosas C, Durruty C, Suárez J (2003) Reproducción en cautiverio de robalo: Una necesidad inaplazable en el sureste mexicano. Panor Acuícola Mag:24-25

Silva CA, Fujimoto RY (2015) Crescimento de tambaqui em resposta a densidade de estocagem em tanquesrede. Acta Amaz 45:323-332. https://doi.org/10.1590/1809-4392201402205

Silva NJ, Lopes MC, Fernandes JBK, Henriques MB (2011) Caracterização dos sistemas de criação e da cadeia produtiva do lambari no estado de São Paulo, Brasil. Informações Eco 41:17-28

SND (2020a) Fish, tilapia, raw. https://nutritiondata.self.com/facts/finfish-and-shellfish-products/9243/2. Accessed 10 Mar 2020

SND (2020b) Fish, catfish, channel, farmed, raw. https://nutritiondata.self.com/facts/finfish-and-shellfishproducts/4256/2. Accessed 10 Mar 2020

Stoneham TR, Kuhn DD, Taylor DP et al (2018) Production of omega-3 enriched tilapia through the dietary use of algae meal or fish oil: improved nutrient value of fillet and offal. PLoS One 13. https://doi.org/10.1371/ journal.pone.0194241

Strauch SM, Wenzel LC, Bischoff A, Dellwig O, Klein J, Schüch A, Wasenitz B, Palm H (2018) Commercial African catfish (Clarias gariepinus) recirculating aquaculture systems: assessment of element and energy pathways with special focus on the phosphorus cycle. Sustain 10:1805. https://doi.org/10.3390/su10061805

Sulis-Costa R, Jimenez JE, Weingartner M, de O Nuñer AP (2013) Efeito da temperatura da água na fase inicial de vida e na proporção sexual do jundiá. Bol Inst Pesca 39:379-388

Sussel FR (2015) Lambaricultura: Pequeno no tamanho, grande no potencial! Panor da Aquicultura 149

Tancredo KR, Gonçalves ELT, Brum A, Acchile M, Hashimoto GSO, Pereira SA, Martins ML (2015) Hematoimmunological and biochemical parameters of silver catfish Rhamdia quelen immunized with live theronts of Ichthyophthirius multifiliis. Fish Shellfish Immunol 45:689-694. https://doi.org/10.1016/j.fsi.2015.05.024 
Tessaro L, Toledo CPR, Neumann G, Krause RA, Meurer F, Natali MRM, Bombardelli RA (2012) Growth and reproductive characteristics of Rhamdia quelen males fed on different digestible energy levels in the reproductive phase. Aquaculture 326-329:74-80. https://doi.org/10.1016/j.aquaculture.2011.11.012

Tilami SK, Sampels S (2018) Nutritional value of fish: lipids, proteins, vitamins, and minerals. Rev Fish Sci Aquac 26:243-253. https://doi.org/10.1080/23308249.2017.1399104

Timmons MB, Ebeling JM (2013) Recirculating aquaculture, 3rd edn. Ithaca Publishing Company LLC, New York

TRIDGE (2020) Overview of global catfish market. https://www.tridge.com/intelligences/catfish. Accessed 25 Jun 2020

Uliana O, da Silva JHS, Neto JR (2001) Partial or total replacement of canola oil by soybean licithin in diets for South American catfish (Rhamdia quelen) larvae, pisces, pimelodidae. Ciência Rural 31:677-681

Urbinati EC, Gonçalves F (2005) Pacu (Piaractus mesopotamicus). In: Baldisserotto B, Gomes LC (eds) Espécies nativas para Piscicultura no Brasil, 2nd edn. UFSM, Santa Maria, pp 225-255

Valladão GMR, Gallani SU, Pilarski F (2018) South American fish for continental aquaculture. Rev Aquac 10: 351-369. https://doi.org/10.1111/raq.12164

Villarroel M, Junge R, Komives T, König B, Plaza I, Bittsánszky A, Joly A (2016) Survey of aquaponics in Europe. Water (Switzerland) 8:468. https://doi.org/10.3390/w8100468

Wilfart A, Prudhomme J, Blancheton J-P, Aubin J (2013) LCA and emergy accounting of aquaculture systems: towards ecological intensification. J Environ Manag 121:96-109. https://doi.org/10.1016/j.jenvman.2013.01.031

Wunderlich SM, Martinez NM (2018) Conserving natural resources through food loss reduction: production and consumption stages of the food supply chain. Int Soil Water Conserv Res 6:331-339

Yamashita MM, Ferrarezi JV, do V Pereira G et al (2020) Autochthonous vs allochthonous probiotic strains to Rhamdia quelen. Microb Pathog 139:103897. https://doi.org/10.1016/j.micpath.2019.103897

Yep B, Zheng Y (2019) Aquaponic trends and challenges-a review. J Clean Prod 228:1586-1599. https://doi. org/10.1016/j.jclepro.2019.04.290

Yildiz HY, Robaina L, Pirhonen J et al (2017) Fish welfare in aquaponic systems: its relation to water quality with an emphasis on feed and faeces-a review. Water 9:13. https://doi.org/10.3390/w9010013

Zhong L, Song C, Chen X, Deng W, Xiao Y, Wang M, Qin Q, Luan S, Kong J, Bian W (2016) Channel catfish in China: historical aspects, current status, and problems. Aquaculture 465:367-373. https://doi.org/10.1016/ j.aquaculture.2016.09.032

Zuanazzi JSG, Delbem ÁCB, Marengoni NG et al (2013) Determinação da composição centesimal de pacu (Piaractus mesopotamicus) cultivados em tanques-rede no Pantanal. SIMPAN. https://ainfo.cnptia.embrapa. br/digital/bitstream/item/93851/1/RE04.pdf. Accessed 19 June 2020

Publisher's note Springer Nature remains neutral with regard to jurisdictional claims in published maps and institutional affiliations.

\section{Affiliations}

\section{Sara M. Pinho ${ }^{1,2}$ • Luiz H. David ${ }^{1}$ • Fabiana Garcia ${ }^{1,3}$ • Karel J. Keesman ${ }^{2}$ - Maria Célia Portella $^{1} \cdot$ Simon Goddek ${ }^{2}$}

1 São Paulo State University (Unesp), Aquaculture Center of Unesp (Caunesp), Jaboticabal, SP 14884-900, Brazil

2 Wageningen University, Mathematical and Statistical Methods Group - Biometris, P.O. Box 16, 6700AA, Wageningen, The Netherlands

3 Fisheries Institute, APTA/SAA, São José do Rio Preto, São Paulo, Brazil 